\title{
Karyological geographic variation of Oligoryzomys nigripes Olfers, 1818 (Rodentia, Cricetidae) from Brazil
}

\author{
Roberta Paresque $^{1}$, Maria José de Jesus Silva ${ }^{2 *}$, Yatiyo Yonenaga-Yassuda ${ }^{2}$ and Valéria Fagundes ${ }^{1}$ \\ ${ }^{1}$ Laboratório de Genética Animal, Departamento de Ciências Biológicas, \\ Centro de Ciências Humanas e Naturais, Universidade Federal do Espírito Santo, Vitória, ES, Brazil. \\ ${ }^{2}$ Departamento de Genética e Biologia Evolutiva, Instituto de Biociências, Universidade de São Paulo, \\ São Paulo, SP, Brazil.
}

\begin{abstract}
The karyotypes of 85 specimens of Oligoryzomys nigripes (Rodentia, Sigmodontinae) collected in the Cerrado and Atlantic Forest of seven states of Brazil were analyzed. Eighty four specimens presented a karyotype with $2 n=62$ and one individual had $2 n=61$ due to a monosomy of the $X$ chromosome. High levels of intra- and inter-population karyotypic variability, due to sex chromosomes heteromorphisms and pericentric inversions in four autosomes (pairs 2, 3, 4 and 8), led to a variation of the autosomal arm numbers (fundamental number, FN) from 78 to 82 . Synaptonemal complex analyses revealed normal meiosis in males heterozygous for pericentric inversions. We found 39 different cytotypes, 27 of which are herein described for the first time. A literature survey revealed 46 described karyotypes for $O$. nigripes. We tested the hypothesis that chromosomal variants frequencies are dependent on geographical distribution and we propose a model for the karyotypical evolution of Oligoryzomys nigripes with $2 \mathrm{n}=62 / \mathrm{FN}=78-82$.
\end{abstract}

Key words: pericentric inversion, Oryzomyini, Oligoryzomys nigripes, Rodentia, clinal variation.

Received: December 13, 2005; Accepted: September 28, 2006.

\section{Introduction}

The genus Oligoryzomys Bangs, 1900 comprises 18 species distributed throughout South America and parts of Central America (Musser and Carleton, 2005; Bonvicino and Weksler, 1998; Weksler and Bonvicino, 2005). According to the last estimates, there are eleven species spread throughout most of the Brazilian biomes: rain forest (Amazonian and Atlantic Forests), open and dry areas (Cerrado, Caatinga and Restinga) and flooding-prone areas (Pampas and Pantanal) (Lima et al., 2003; Weksler and Bonvicino, 2005).

Specimens with very similar external morphology and karyotypes $(2 n=62)$ collected in Brazil were classified as three different species: $O$. nigripes Olfers, 1818; $O$. delticola Thomas, 1917; and O. eliurus Wagner, 1845. Geographic distribution was the main feature used in the identification of specimens (Myers and Carleton 1981; Bonvicino and Weksler, 1998).

Send correspondence to Valéria Fagundes. Departamento de Ciências Biológicas, Centro de Ciências Humanas e Naturais, Universidade Federal do Espírito Santo, Av. Marechal Campos 1486, 29040-090 Maruípe, Vitória, Espírito Santo, Brazil. E-mail: vfagunde@npd.ufes.br. *Present address: Instituto Butantã, São Paulo, SP, Brazil.
Oligoryzomys nigripes was first described as Mus nigripes (Olfers 1818). Over a century later, Myers and Carleton (1981) proposed a neotype for O. nigripes from a sample collected in Paraguay, near the type locality. The specimens showed $2 \mathrm{n}=62$ and $\mathrm{FN}=80-81$.

Specimens collected in the Paraná river delta (Buenos Aires, Argentina) were considered distinct from the sympatric species $O$. flavescens and were classified as Oligoryzomys delticola by Thomas (1917), who disregarded the original description of $O$. nigripes (Olfers, 1818). Brum-Zorrilla et al. (1988) reported the karyotypes of $O$. delticola from Uruguay with $2 \mathrm{n}=62 / \mathrm{FN}=80-81$, very similar to those described for $O$. nigripes by Myers and Carleton (1981). Sbalqueiro (PhD Thesis. Universidade Federal do Rio Grande do Sul. Porto Alegre, Brazil, 1989) described karyotypes with $2 \mathrm{n}=62 / \mathrm{FN}=79-82$ for $O$. delticola from Southern Brazil. Espinosa and Reig (1991) studied specimens of $O$. delticola collected in the type locality (Buenos Aires) and found karyotypes with $2 \mathrm{n}=62 / \mathrm{FN}=81-82$. More recently, Bonvicino and Weksler (1998), based on karyotypes and GTG-banding similarities, considered $O$. delticola as a junior synonym of $O$. nigripes.

Wagner (1845) described Oligoryzomys eliurus from the type locality Itararé, São Paulo, Brazil, but did not per- 
form any comparative analyses with other Oligoryzomys species. Morphological and cranial studies later indicated that $O$. eliurus was a junior synonym of $O$. nigripes (Cabrera, 1961; Myers and Carleton, 1981; Bonvicino and Weksler 1998). Andrades-Miranda et al. (2001) reported karyotypes with $2 \mathrm{n}=62 / \mathrm{FN}=64$ for $O$. eliurus and $2 \mathrm{n}=62 / \mathrm{FN}=79-82$ for $O$. nigripes. Specimens of both species were found in sympatry in the Cerrado of the state of Goiás, Brazil. Bonvicino and Weksler (1998) identified a karyotype with $2 \mathrm{n}=62 / \mathrm{FN}=64$ in specimens of $O$. fornes $i$ Massoia (1973), collected in Goiás.

Considering the morphological and karyological data reported in the literature, we support the status of $O$. delticola and $O$. eliurus as junior synonyms of $O$. nigripes and consider the karyotypes with $2 \mathrm{n}=62 / \mathrm{FN}=78-82$ to be related to $O$. nigripes.

Most $O$. nigripes populations analyzed showed pericentric inversion polymorphisms in autosome pairs 2, 3, 4 and 8 (Brum-Zorrilla et al., 1988; Almeida and YonenagaYassuda, 1991; Bonvicino et al., 2001). The pericentric inversions did not seem to result in any selective disadvantages for heterozygotes (Bonvicino et al., 2001).

In this work, we present data on the karyotypes of 85 specimens from wild populations of $O$. nigripes from Brazil, which showed high levels of sex chromosome and autosome variation. The compilation of our data with litera- ture reports revealed the existence of 46 karyotype variants (cytotypes) with $2 \mathrm{n}=61-62$ and $\mathrm{FN}=78-82$, in specimens from Brazil and Uruguay.

\section{Material and Methods}

\section{Specimens}

Our sample consisted of 85 specimens of Oligoryzomys nigripes trapped in seven states of Brazil in areas of Caatinga (Ceará), Cerrado (Minas Gerais and Mato Grosso do Sul), and Atlantic forest (Bahia, Espírito Santo, São Paulo and Rio Grande do Sul) (Table 1, Figure 1, Appendix 1). Skins and skulls were deposited at the Museu de Zoologia da Universidade de São Paulo (MZUSP) and Museu de Biologia Professor Mello Leitão (MBML).

\section{Cytogenetic studies}

Metaphase preparations were obtained from bone marrow and testis, after in vivo injection of a $0.1 \%$ colchicine solution $(1 \mathrm{~mL} / 100 \mathrm{~g}$ of body weight). Cells were suspended in a $0.075 \mathrm{M} \mathrm{KCl}$ solution for $25-30 \mathrm{~min}$ at $37^{\circ} \mathrm{C}$, fixed in 3:1 methanol: acetic acid, spread onto clean slides and air-dried. GTG- and CBG-banding were performed according to Seabright (1971) and Sumner (1972), respectively. At least 20 metaphases per individual were analyzed to define the diploid and fundamental numbers

Table 1 - Cytotypes of Oligoryzomys nigripes with $2 n=62$ and FN $=78-82$.

\begin{tabular}{|c|c|c|c|c|c|c|c|c|c|c|c|}
\hline \multirow[t]{2}{*}{ Cytotype } & \multirow[t]{2}{*}{$2 n$} & \multirow[t]{2}{*}{$\mathrm{FN}$} & \multicolumn{4}{|c|}{ Autosome pairs ${ }^{1}$} & \multirow{2}{*}{$\begin{array}{l}\text { Sexual } \\
\text { pair }^{2}\end{array}$} & \multirow[t]{2}{*}{$\mathrm{n}$} & \multirow[t]{2}{*}{ Specimens $^{3}$} & \multirow[t]{2}{*}{ Locality $^{4}$} & \multirow[t]{2}{*}{ Reference $^{5}$} \\
\hline & & & 2 & 3 & 4 & 8 & & & & & \\
\hline 1 & 62 & 78 & A & A & M & M & $\mathrm{XaXb}$ & 1 & CIT986 & 23 & Present study \\
\hline 2 & 62 & 78 & $\mathrm{~A}$ & $\mathrm{~A}$ & M & M & $\mathrm{XaYa}$ & 3 & CIT990, CIT992, CIT1018 & 23 & Present study \\
\hline 3 & 62 & 78 & A & A & M & M & $\mathrm{XaYc}$ & 1 & CIT 1263 & 24 & Present study \\
\hline 4 & 62 & 78 & M & A & A & M & $\mathrm{XcXa}$ & 2 & - & 1 & Zanchin $1988^{5 \mathrm{a}}$ \\
\hline 5 & 62 & 79 & M & A & $\mathrm{H}$ & M & $\mathrm{XaXb}$ & 1 & LGA116 & 2 & Present study \\
\hline 6 & 62 & 79 & M & A & M & $\mathrm{H}$ & $\mathrm{XaYa}$ & 1 & LGA391 & 3 & Present study \\
\hline 7 & 62 & 79 & M & A & M & $\mathrm{H}$ & $\mathrm{XaXa}$ & 1 & LGA413 & 4 & Present study \\
\hline 8 & 62 & 80 & M & $\mathrm{H}$ & $\mathrm{H}$ & M & $\mathrm{XcXc}$ & 1 & LGA115 & 2 & Present study \\
\hline 9 & 62 & 80 & M & $\mathrm{H}$ & $\mathrm{H}$ & M & $\mathrm{XaXb}$ & 1 & LGA404 & 4 & Present study \\
\hline \multirow[t]{2}{*}{10} & 62 & 80 & M & A & M & M & $\mathrm{XaXa}$ & 1 & CIT1283 & 19 & Present study \\
\hline & & & & & & & & 1 & BIO837 & 5 & Present study ${ }^{5 b}$ \\
\hline \multirow[t]{4}{*}{11} & 62 & 80 & M & A & M & M & $\mathrm{XaXb}$ & 1 & LGA916 & 7 & Present study \\
\hline & & & & & & & & 1 & CIT355 & 15 & Present study \\
\hline & & & & & & & & 1 & CIT117 & 8 & Present study ${ }^{5 b}$ \\
\hline & & & & & & & & 1 & - & 6 & Zanchin $1988^{5 \mathrm{a}}$ \\
\hline 12 & 62 & 80 & M & A & M & M & $\mathrm{XaXc}$ & 1 & - & 9 & Zanchin $1988^{5 \mathrm{a}}$ \\
\hline 13 & 62 & 80 & M & A & M & M & $\mathrm{XbXb}$ & 1 & LGA619 & 10 & Present study \\
\hline 14 & 62 & 80 & M & A & M & M & $\mathrm{XcXc}$ & 2 & - & 6 & Zanchin $1988^{5 \mathrm{a}}$ \\
\hline \multirow[t]{3}{*}{15} & 62 & 80 & M & A & M & M & $\mathrm{XaYa}$ & 2 & LGA615, LGA620 & 10 & Present study \\
\hline & & & & & & & & 1 & CIT1051 & 19 & Present study \\
\hline & & & & & & & & 10 & - & 6 & Zanchin $1988^{5 \mathrm{a}}$ \\
\hline \multirow[t]{2}{*}{16} & 62 & 80 & M & $\mathrm{A}$ & M & M & $\mathrm{XaYb}$ & 1 & LGA101 & 2 & Present study \\
\hline & & & & & & & & 1 & LGA408 & 4 & Present study \\
\hline
\end{tabular}


Table 1 (cont.)

\begin{tabular}{|c|c|c|c|c|c|c|c|c|c|c|c|}
\hline \multirow[t]{2}{*}{ Cytotype } & \multirow[t]{2}{*}{$2 n$} & \multirow[t]{2}{*}{$\mathrm{FN}$} & \multicolumn{4}{|c|}{ Autosome pairs ${ }^{1}$} & \multirow{2}{*}{$\begin{array}{l}\text { Sexual } \\
\text { pair }^{2}\end{array}$} & \multirow[t]{2}{*}{$\mathrm{n}$} & \multirow[t]{2}{*}{ Specimens $^{3}$} & \multirow[t]{2}{*}{ Locality $^{4}$} & \multirow[t]{2}{*}{ Reference $^{5}$} \\
\hline & & & 2 & 3 & 4 & 8 & & & & & \\
\hline & & & & & & & & 1 & CIT133 & 14 & Present study ${ }^{5 b}$ \\
\hline & & & & & & & & 2 & CIT122, CIT137 & 8 & Present study ${ }^{5 b}$ \\
\hline \multirow[t]{2}{*}{17} & 62 & 80 & M & A & M & M & $\mathrm{XaYc}$ & 1 & LGA45 & 2 & Present study \\
\hline & & & & & & & & 1 & - & 11 & Svartman $1989^{5 b}$ \\
\hline \multirow[t]{3}{*}{18} & 62 & 80 & M & A & M & M & $\mathrm{XbYc}$ & 1 & LGA388 & 3 & Present study \\
\hline & & & & & & & & 1 & - & 9 & Zanchin $1988^{5 a}$ \\
\hline & & & & & & & & 1 & CIT1038 & 19 & Present study \\
\hline 19 & 62 & 80 & M & A & M & M & $\mathrm{XaYd}$ & 1 & CIT192 & 14 & Present study \\
\hline \multirow[t]{2}{*}{20} & 62 & 80 & M & $\mathrm{H}$ & M & M & $\mathrm{XcYa}$ & 1 & LGA65 & 2 & Present study \\
\hline & & & & & & & & 2 & - & 6 & Zanchin $1988^{5 \mathrm{a}}$ \\
\hline 21 & 61 & 81 & M & $\mathrm{H}$ & M & M & $\mathrm{Xa} 0$ & 1 & LGA125 & 2 & Present study \\
\hline \multirow[t]{4}{*}{22} & 62 & 81 & M & $\mathrm{H}$ & M & M & $\mathrm{XaXa}$ & 2 & LGA39, LGA64 & 2 & Present study \\
\hline & & & & & & & & 2 & - & 9 & Zanchin $1988^{5 \mathrm{a}}$ \\
\hline & & & & & & & & 2 & CIT120, CIT125 & 8 & Present study ${ }^{5 b}$ \\
\hline & & & & & & & & 4 & - & 6 & Zanchin $1988^{5 \mathrm{a}}$ \\
\hline \multirow[t]{8}{*}{23} & 62 & 81 & M & $\mathrm{H}$ & M & M & $\mathrm{XaXb}$ & 2 & LGA182, LGA820 & 2 & Present study \\
\hline & & & & & & & & 1 & LGA928 & 12 & Present study \\
\hline & & & & & & & & 3 & BIO793, BIO794, CIT121 & 8 & Present study ${ }^{5 b}$ \\
\hline & & & & & & & & 1 & CIT963 & 17 & Present study \\
\hline & & & & & & & & 1 & CIT329 & 18 & Present study \\
\hline & & & & & & & & 1 & CIT350 & 21 & Present study \\
\hline & & & & & & & & 1 & - & 8 & Zanchin $1988^{5 \mathrm{a}}$ \\
\hline & & & & & & & & 1 & - & 6 & Zanchin $1988^{5 \mathrm{a}}$ \\
\hline 24 & 62 & 81 & M & $\mathrm{H}$ & M & M & $\mathrm{XaXc}$ & 5 & - & 6 & Zanchin $1988^{5 \mathrm{a}}$ \\
\hline 25 & 62 & 81 & M & $\mathrm{H}$ & M & M & $\mathrm{XbXc}$ & 2 & LGA114, LGA183 & 2 & Present study \\
\hline 26 & 62 & 81 & M & $\mathrm{H}$ & M & M & $\mathrm{XbXb}$ & 1 & LGA882 & 13 & Present study \\
\hline \multirow[t]{4}{*}{27} & 62 & 81 & M & $\mathrm{H}$ & M & M & $\mathrm{XaYa}$ & 1 & LGA58 & 2 & Present study \\
\hline & & & & & & & & 1 & CIT351 & 21 & Present study \\
\hline & & & & & & & & 1 & - & 9 & Zanchin $1988^{5 \mathrm{a}}$ \\
\hline & & & & & & & & 6 & - & 6 & Zanchin $1988^{5 \mathrm{a}}$ \\
\hline \multirow[t]{2}{*}{28} & 62 & 81 & M & $\mathrm{H}$ & M & M & $\mathrm{XaYb}$ & 1 & LGA403 & 4 & Present study \\
\hline & & & & & & & & 1 & CIT1042 & 19 & Present study \\
\hline 29 & 62 & 81 & M & $\mathrm{H}$ & M & M & $\mathrm{XaYc}$ & 4 & $\begin{array}{l}\text { LGA55, LGA56, LGA59, } \\
\text { LGA63 }\end{array}$ & 2 & Present study \\
\hline & & & & & & & & 2 & BIO633, CIT123 & 8 & Present study ${ }^{5 b}$ \\
\hline & & & & & & & & 1 & CIT939 & 16 & Present study \\
\hline & & & & & & & & 1 & BIO831 & 5 & Present study ${ }^{5 b}$ \\
\hline 30 & 62 & 81 & M & $\mathrm{H}$ & M & M & $\mathrm{XaYd}$ & 1 & LGA406 & 4 & Present study \\
\hline & & & & & & & & 1 & BIO797 & 8 & Present study ${ }^{5 b}$ \\
\hline & & & & & & & & 1 & CIT339 & 14 & Present study \\
\hline 31 & 62 & 81 & M & $\mathrm{H}$ & M & M & $\mathrm{XbYc}$ & 1 & LGA122 & 2 & Present study \\
\hline 32 & 62 & 81 & M & $\mathrm{H}$ & M & M & $\mathrm{XcYa}$ & 1 & LGA126 & 2 & Present study \\
\hline 33 & 62 & 81 & M & $\mathrm{H}$ & M & M & $\mathrm{XcYb}$ & 1 & LGA110 & 2 & Present study \\
\hline & & & & & & & & 3 & - & 6 & Zanchin $1988^{5 \mathrm{a}}$ \\
\hline 34 & 62 & 81 & M & $\mathrm{H}$ & M & M & $\mathrm{XcYd}$ & 1 & LGA927 & 7 & Present study \\
\hline 35 & 62 & 82 & M & M & M & M & $\mathrm{Xa0}$ & 1 & - & 9 & Zanchin $1988^{5 \mathrm{a}}$ \\
\hline 36 & 62 & 82 & M & M & M & M & $\mathrm{XaXa}$ & 1 & LGA124 & 2 & Present study \\
\hline & & & & & & & & 1 & CIT119 & 8 & Present study ${ }^{5 b}$ \\
\hline & & & & & & & & 1 & CIT1283 & 20 & Present study \\
\hline & & & & & & & & 1 & CIT343 & 21 & Present study \\
\hline 37 & 62 & 82 & M & $\mathrm{M}$ & M & M & $\mathrm{XaXb}$ & 1 & LGA108 & 2 & Present study \\
\hline & & & & & & & & 2 & LGA917, LGA918 & 7 & Present study \\
\hline & & & & & & & & 1 & CIT57 & 8 & Present study ${ }^{5 b}$ \\
\hline
\end{tabular}


Table 1 (cont.)

\begin{tabular}{|c|c|c|c|c|c|c|c|c|c|c|c|}
\hline \multirow[t]{2}{*}{ Cytotype } & \multirow[t]{2}{*}{$2 n$} & \multirow[t]{2}{*}{$\mathrm{FN}$} & \multicolumn{4}{|c|}{ Autosome pairs ${ }^{1}$} & \multirow{2}{*}{$\begin{array}{c}\text { Sexual } \\
\text { pair }^{2}\end{array}$} & \multirow[t]{2}{*}{$\mathrm{n}$} & \multirow[t]{2}{*}{ Specimens $^{3}$} & \multirow[t]{2}{*}{ Locality $^{4}$} & \multirow[t]{2}{*}{ Reference $^{5}$} \\
\hline & & & 2 & 3 & 4 & 8 & & & & & \\
\hline & & & & & & & & 1 & CIT186 & 14 & Present study \\
\hline & & & & & & & & 1 & CIT344 & 21 & Present study \\
\hline 38 & 62 & 82 & M & M & M & M & $\mathrm{XaXc}$ & 3 & - & 6 & Zanchin $1988^{50}$ \\
\hline \multirow[t]{4}{*}{39} & 62 & 82 & M & M & M & M & $\mathrm{XaYa}$ & 1 & LGA7 & 2 & Present study \\
\hline & & & & & & & & 1 & - & 9 & Zanchin $1988^{5}$ \\
\hline & & & & & & & & 7 & - & 6 & Zanchin $1988^{5}$ \\
\hline & & & & & & & & 1 & CIT55 & 8 & Present study ${ }^{5 b}$ \\
\hline 40 & 62 & 82 & M & M & M & M & $\mathrm{XaYb}$ & 1 & CIT216 & 14 & Present study \\
\hline 41 & 62 & 82 & M & M & M & M & $\mathrm{XaYc}$ & 1 & CIT1280 & 22 & Present study \\
\hline \multirow[t]{2}{*}{42} & 62 & 82 & M & M & M & M & $\mathrm{XcYc}$ & 1 & LGA113 & 2 & Present study \\
\hline & & & & & & & & 1 & CIT349 & 21 & Present study \\
\hline 43 & 62 & 82 & M & M & M & M & $\mathrm{XaYd}$ & 1 & BIO795 & 8 & Present study ${ }^{5 b}$ \\
\hline \multirow[t]{2}{*}{44} & 62 & 82 & M & M & M & M & $\mathrm{XbYb}$ & 1 & LGA160 & 2 & Present study \\
\hline & & & & & & & & 1 & - & 6 & Zanchin $1988^{5 a}$ \\
\hline \multirow[t]{2}{*}{45} & 62 & 82 & M & M & M & M & $\mathrm{XbYc}$ & 1 & CIT124 & 8 & Present study ${ }^{5 b}$ \\
\hline & & & & & & & & 1 & BIO833 & 5 & Present study ${ }^{5 b}$ \\
\hline 46 & 62 & 82 & M & M & M & M & $\mathrm{XcYb}$ & 1 & - & 6 & Zanchin $1988^{5}$ \\
\hline
\end{tabular}

Total 143

${ }^{1} \mathrm{~A}=$ acrocentric, $\mathrm{H}=$ heteromorphic (one acrocentric and one submetacentric), $\mathrm{M}=$ metacentric.

${ }^{2} \mathrm{Xa}=$ large submetacentric, $\mathrm{Xb}=$ large subtelocentric, $\mathrm{Xc}=$ large metacentric; $\mathrm{Ya}=$ medium metacentric, $\mathrm{Yb}=$ small submetacentric; $\mathrm{Yc}=$ medium submetacentric; Yd = small acrocentric (according to Almeida and Yonenaga-Yassuda, 1991). Svartman (1989) paired the Xa cromosome as being the homologue of chromosome 3.

${ }^{3}$ LGA, CIT and BIO followed by a number correspond to catalogue numbers assigned to specimens in the Laboratório de Genética Animal (UFES) and Laboratório de Citogenética de Vertebrados (USP).

${ }^{4}$ Locality: 1) Rio de Una, Bahia; 2) Santa Teresa, Espírito Santo; 3) Cariacica, Espírito Santo; 4) Maquiné, Rio Grande do Sul; 5) Iporanga, São Paulo; 6) Morro Alto, Emboaba, Faxinal, Alto Ferrabraz e Picada Verão, Rio Grande do Sul; 7) São Francisco de Paula, Rio Grande do Sul; 8) Fazenda Intervales, São Paulo; 9) Venda Nova do Imigrante, Espírito Santo; 10) Bodoquena, Mato Grosso do Sul; 11) Brasília, Distrito Federal; 12) Águas de Santa Bárbara, São Paulo; 13) Santa Maria de Jetibá, Espírito Santo; 14) Iguape, São Paulo; 15) Araçariguama, São Paulo; 16) Luiz Antonio, São Paulo; 17) Santo Antonio, São Paulo; 18) Ribeirão Preto, São Paulo; 19) Pilar do Sul, São Paulo; 20) Juquiá, São Paulo; 21) Caxambu, Minas Gerais; 22) Serra da Canastra, Minas Gerais; 23) Pacoti, Ceará; 24) Morro do Chapéu, Bahia.

${ }^{5}$ Zanchin NIT (1988) Estudos cromossômicos em orizominos e equimídeos da Mata Atlântica. PhD thesis. Universidade Federal do Rio Grande do Sul. Porto Alegre. Rio Grande do Sul. Brazil. ${ }^{5 b}$ Also presented in Silva MJJ (1994) Estudos cromossômicos e de complexos sinaptonêmicos em roedores brasileiros da tribo Oryzomyini (Cricetidae, Rodentia). Master Thesis. São Paulo, São Paulo, Brazil. ${ }^{5 \mathrm{c}}$ Svartman M (1989) Levantamento cariotípico de roedores da região do Distrito Federal. Master Thesis. São Paulo, São Paulo, Brazil.

( $2 \mathrm{n}$ and FN). Karyotypes were arranged according to Almeida and Yonenaga-Yassuda (1991).

Fluorescence in situ hybridization (FISH) with the telomeric sequence (TTAGGG) $)_{n}$ was performed in cells from two specimens that were heteromorphic for a pericentric inversion in pair $3(3 \mathrm{H})$. FISH was performed with the "All Human Telomeres Kit" (P5097-DG5, Oncor), according to the supplier' s protocol. The chromosome preparations were analyzed under a Zeiss Axiophot microscope and photographed with Ektachrome 400 color slide film (Kodak).

Synaptonemal complexes (SC) were analyzed according to the procedure described by Loidl et al. (1991) on testes spreads from two males heteromorphic for inversions in pair 3. The chromosome preparations were stained with silver nitrate and analyzed with both light and electron microscopy. Meiotic phases were identified according to Greenbaum et al. (1986).

\section{Statistical analyses}

The karyotypes of all Oligoryzomys specimens with $2 \mathrm{n}=62 / \mathrm{FN}=78-82$ reported in the literature were analyzed and compared. A total of 467 specimens referred to as either O. delticola (Brum-Zorrilla et al., 1988; Espinosa and Reig 1991) or O. nigripes (Myers and Carleton, 1981; Zanchin, 1988; Almeida and Yonenaga-Yassuda, 1991; Geise, 1995; Bonvicino et al., 2001) were included in the analyses (Table 2).

A total of 143 out of the 467 specimens were used to determine the different karyotype variants (cytotypes). Only descriptions that allowed the morphological identification of all the autosomes and sex chromosomes were considered (Table 1).

The frequencies of the variants of chromosomes $3, \mathrm{X}$ and $\mathrm{Y}$ were plotted on a map comprising the following areas: Espírito Santo and Rio de Janeiro (ES-RJ), Santa Catarina and Rio Grande do Sul (SC-RS), São Paulo (SP), 


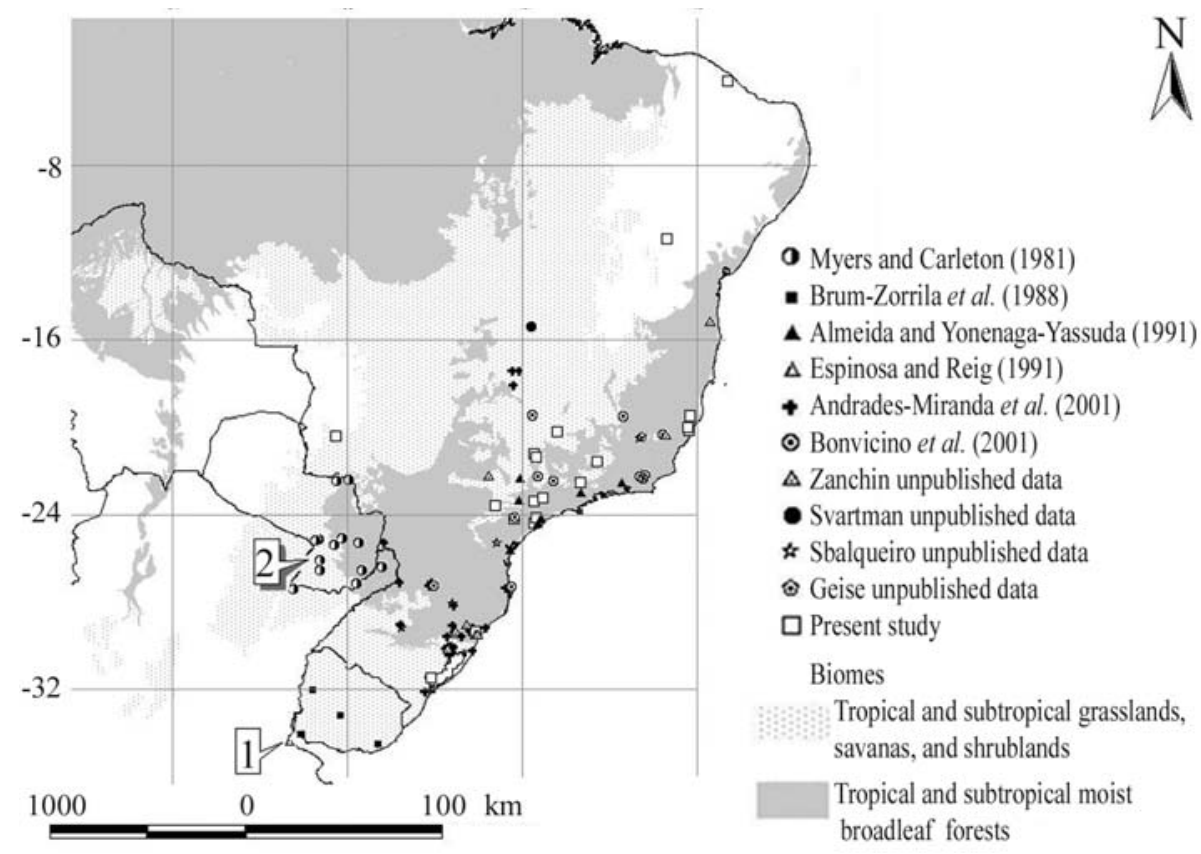

Figure 1 - Collection localities of Oligoryzomys nigripes $(2 \mathrm{n}=62 / \mathrm{FN}=78-82) .1$ and 2 represent the type localities for Oligoryzomys delticola and Oligoryzomys nigripes, respectively.

Minas Gerais MG), Bahia (BA), Ceará (CE) and Mato Grosso do Sul (MS) in Brazil; and Uruguay (URU).

The correlation between the frequencies of the chromosome variants and the geographic areas was tested with the chi-square test $\left(\chi^{2}\right)$ with a p-value of 0.05 , assuming that the chromosome heteromorphisms are randomly distributed in the populations.

\section{Results}

\section{Karyotype variability}

Thirty-nine cytotypes were detected in our sample, due to variations of chromosomes 2, 3, 4, 8, and of the sex chromosomes. Twenty-seven of these cytotypes had not yet been described. A literature review showed the presence of 46 cytotypes among 143 O. nigripes specimens (Table 1).

Eighty four out of 85 specimens of Oligoryzomys nigripes presented $2 \mathrm{n}=62$. One specimen from Espírito Santo (LGA 125) had $2 n=61$ due to a monosomy of the $X$ chromosome (Table 1). The number of autosome arms (FN) varied from 78 to 82 as a result of pericentric inversions in pairs 2, 3, 4 and 8. Heteromorphisms of the $\mathrm{X}$ and $\mathrm{Y}$ chromosomes were also detected.

In the karyotypes analyzed, pair 1 was a large submetacentric; pair 2 was a large submetacentric (2SM) or a large acrocentric (2A); pairs 3 and 4 were present as homomorphic metacentrics $(3 \mathrm{M} / 4 \mathrm{M})$, homomorphic acrocentrics $(3 \mathrm{~A} / 4 \mathrm{~A})$ or were heteromorphic metacentric/acrocentric $(3 \mathrm{H} / 4 \mathrm{H})$; pair 8 was metacentric $(8 \mathrm{M})$ or heteromorphic metacentric/acrocentric (8H); pairs 5, 6, 7, 9, 10 and 11 were medium to small meta/submetacentrics; and pairs
12 to 30 were acrocentrics with gradual variation in size (Figure 2 and 3a). G-banding patterns analyses allowed us to confirm that pericentric inversions were responsible for the polymorphisms of pairs 2, 3, 4 and 8 . The acrocentric form of pair 2 is herein described for the first time.

Three different morphologies were observed for the $\mathrm{X}$ chromosome and four $\mathrm{Y}$ chromosome variants were identified. The sex chromosomes were classified as $\mathrm{Xa}, \mathrm{Xb}$, $\mathrm{Ya}, \mathrm{Yb}$ and $\mathrm{Yc}$ according to Almeida and Yonenaga-Yassuda (1991). The Xc and Yd forms are herein described for the first time. $\mathrm{Xa}$ is a large submetacentric, $\mathrm{Xb}$ is a large subtelocentric and Xc is a large metacentric, all similar in size to pair 1, although Xa and Xc are slightly larger than $\mathrm{Xb}$. Ya is a medium metacentric, similar in size to the long arm of $\mathrm{Xa}$; $\mathrm{Yb}$ is a small submetacentric, equivalent in size to half of the long arm of Xa; Yc is a medium submetacentric, similar in size to the long arm of Xa; and $\mathrm{Yd}$ is a small subtelocentric, equivalent in size to half of the long arm of Xa (Figure 3b). The size variation of the $\mathrm{X}$ and $\mathrm{Y}$ chromosomes were due to differences in constitutive heterochromatin content.

After FISH with a telomeric probe, signals were restricted to the telomeres of all chromosomes. No interstitial telomeric sites (ITS) neither signals associated with heterochromatic regions were observed (Figure 3c).

Analyses of meiotic cells revealed that the heterochromatic short arm of the $\mathrm{X}$ chromosome pairs with the euchromatic long arm of the Y chromosome (Figure 4a-b). Synapsis starts interstitially and proceeds towards the tips of the chromosomes. At their maximum level of pairing, 
Table 2 - Constitution of pair 3 in Oligoryzomys nigripes with $2 \mathrm{n}=62 / \mathrm{FN}=78-82$.

\begin{tabular}{|c|c|c|c|c|c|c|c|}
\hline \multirow[t]{2}{*}{ Referred as } & \multirow[t]{2}{*}{$2 \mathrm{n}$} & \multirow[t]{2}{*}{ FN } & \multicolumn{3}{|c|}{ Pair 3 form } & \multirow[t]{2}{*}{$n$} & \multirow[t]{2}{*}{ Reference $^{1}$} \\
\hline & & & $3 \mathrm{~A}$ & $3 \mathrm{H}$ & $3 \mathrm{M}$ & & \\
\hline O. nigripes & 62 & $78-82$ & 20 & 23 & 14 & 57 & Zanchin $1988^{1 \mathrm{a}}$ \\
\hline O. nigripes & 62 & $80-82$ & - & 1 & - & 1 & Svartman $1989^{1 \mathrm{~b}}$ \\
\hline O. delticola & 62 & $79-82$ & 18 & 10 & 7 & 35 & Sbalqueiro $1989^{1 \mathrm{c}}$ \\
\hline O. nigripes & 62 & $80-82$ & 38 & 65 & 36 & 139 & Almeida and Yonenaga-Yassuda 1991 \\
\hline O. nigripes & 62 & 82 & - & - & 6 & 6 & Geise $1995^{1 \mathrm{~d}}$ \\
\hline O. nigripes & 62 & $80-82$ & 8 & 50 & 39 & 97 & Bonvicino et al. 2001 \\
\hline O. delticola & 62 & $80-81$ & 4 & 3 & - & 7 & Brum-Zorrilla et al. 1988 \\
\hline O. delticola & 62 & $81-82$ & - & 1 & 4 & 5 & Espinosa and Reig 1991 \\
\hline$O$. nigripes & 62 & $80-81$ & NI & NI & NI & 35 & Myers and Carleton 1981 \\
\hline$O$. nigripes & 62 & $78-82$ & 26 & 39 & 20 & 85 & Present study \\
\hline
\end{tabular}

$2 \mathrm{n}=$ diploid number; $\mathrm{FN}=$ fundamental number, i.e. number of autosomal arms; $3 \mathrm{~A}=$ acrocentric pair $3 ; 3 \mathrm{H}=$ heteromorphic pair $3 ; 3 \mathrm{M}=$ metacentric pair $3 ; \mathrm{n}=$ number of individuals. $\mathrm{NI}=$ not identified.

${ }^{1 a}$ Zanchin NIT (1988) Estudos cromossômicos em orizominos e equimídeos da Mata Atlântica. PhD thesis. Universidade Federal do Rio Grande do Sul. Porto Alegre. Rio Grande do Sul. Brazil. ${ }^{\text {b }}$ Svartman M (1989) Levantamento cariotípico de roedores da região do Distrito Federal. Master Thesis. São Paulo, São Paulo, Brasil. ${ }^{\text {Ic } S b a l q u e i r o ~ I J ~(1989) ~ A n a ́ l i s e s ~ c r o m o s s o ̂ m i c a s ~ e ~ f i l o g e n e ́ t i c a s ~ e m ~ a l g u m a s ~ e s p e ́ c i e s ~ d e ~ r o e d o r e s ~ d a ~ r e g i a ̃ o ~ S u l ~ d o ~ B r a s i l . ~}$ PhD Thesis. Porto Alegre, Rio Grande do Sul, Brazil. ${ }^{1 \mathrm{~d}}$ Geise L (1995) Os roedores Sigmodontinae (Rodentia, Muridae) do Estado do Rio de Janeiro: sistemática, citogenética, distribuição e variação geográfica. PhD Thesis. Universidade Federal do Rio de Janeiro. Rio de Janeiro, Rio de Janeiro, Brazil.

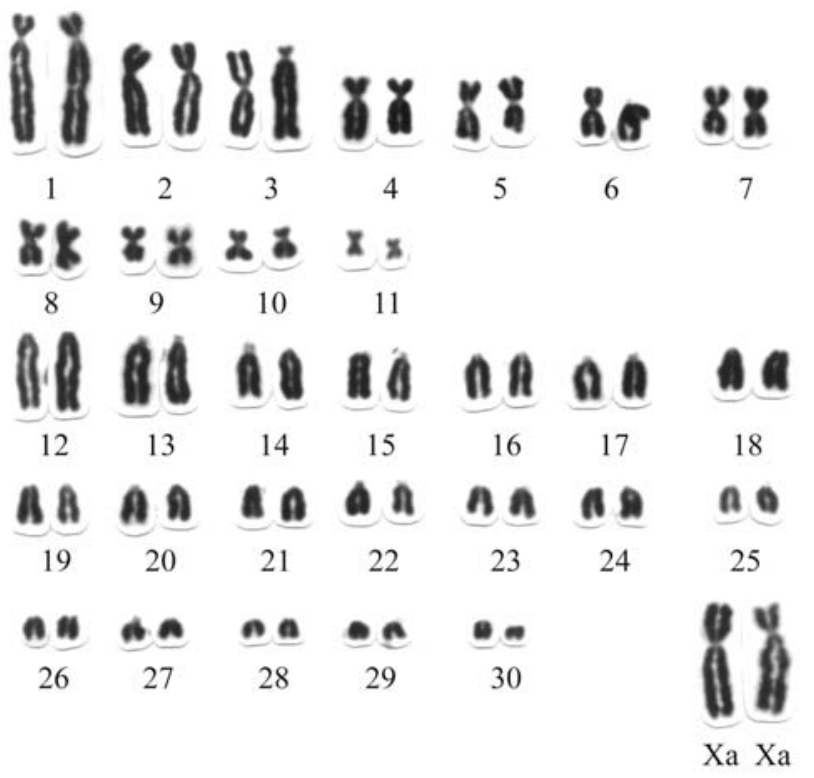

Figure 2 - Conventional stained karyotype of Oligoryzomys nigripes $(2 \mathrm{n}=$ $62 / \mathrm{FN}=80$ ). Pair 3 is heteromorphic and the $\mathrm{X}$ chromosomes are large submetacentrics $(\mathrm{XaXa})$.

half of the $\mathrm{Y}$ and about $20 \%$ of the $\mathrm{X}$ were paired (Figure 4c-d).

\section{Geographic patterns of chromosome variation}

The submetacentric form of pair 2 occurred in all populations, except from Ceará, where the acrocentric form was exclusive. Pair 4 was metacentric in all geographic ar-

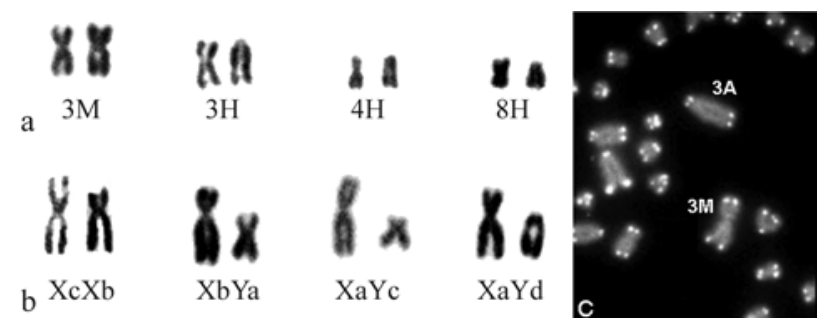

Figure 3 - (a) Variation of autosome pairs 3, 4 and 8: $\mathrm{H}=$ heteromorphic, and $\mathrm{M}=$ metacentric; (b) interindividual variability of the sex chromosomes; (c) fluorescence in situ hybridization with a telomeric probe revealed signals only at the telomeres of the heteromorphic pair 3 .

eas, except for two heteromorphic specimens from Bahia. The metacentric pair 8 was the only variant present in most areas, except for a low frequency of heteromorphic individuals in samples from ES-RJ, SC-RS and SP.

The analysis of the geographic distribution of pair 3 $(3 \mathrm{~A}, 3 \mathrm{H}$ and $3 \mathrm{M}$ ) and $\mathrm{Y}$ chromosome variants ( $\mathrm{Ya}, \mathrm{Yb}, \mathrm{Yc}$ and $\mathrm{Yd}$ ) showed a clinal distribution pattern. The cline starts in Central Brazil and progresses to the south (SC-RS and SP) towards the northeast (BA-CE). The acrocentric form of chromosome $3(3 \mathrm{~A})$ was the only one observed in the central region (MS), its frequency decreased in the URU and SC-RS regions (40-57\%) and SP, mg, ES-RJ $(0-50 \%)$ and it was exclusive in the northernmost populations (100\%). Accordingly, $3 \mathrm{M}$ was very frequent in the areas of SP, MG, ES-RJ (38-76\%) and less frequent in the southern and central regions (SP, SC-RS, URU and MS) $(0-20 \%)$ (Figure $5 \mathrm{a})$. The chi-square test pointed to a non- 


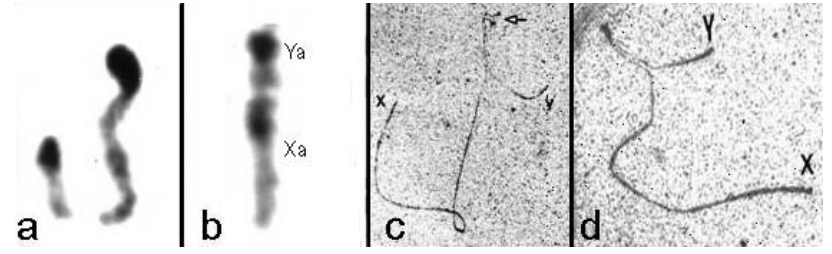

Figure 4 - (a-b) C-banded sex chromosomes of $O$. nigripes in diplotene: (a) dissociated sex chromosomes; (b) end-to-end pairing of the long arm of $\mathrm{Ya}$ and the short arm of Xa; (c-d) Electron micrography of silver-stained spreads of early pachytene nuclei: (c) pairing of $\mathrm{Xa}$ and $\mathrm{Yb}$ with interstitial synaptic initiation; (d) total pairing of the short arm of Xa and the long arm of $\mathrm{Yb}$; unpaired axes show heteropicnosis (arrow). $\mathrm{Xa}=$ large submetacentric, $\mathrm{Ya}=$ medium submetacentric, $\mathrm{Yb}=$ small metacentric.

random geographic distribution of chromosome 3 variants $(\mathrm{p}$-value $=0.00)$.

Ya was the most frequently found $\mathrm{Y}$ chromosome variant. It predominated in the central (MS), southern (RS-SC) and northern (BA, CE) areas, and its frequency decreased in the southern areas (SP, MG, ES-RJ). Yb was predominant in populations from $\mathrm{SP}$ and $\mathrm{Yc}$ was predominant in ES-RJ populations. Yd was the least frequent $\mathrm{Y}$ chromosome variant and it was only found in SP and SC-RS samples (Figure 5b). Clinal variation was observed for $\mathrm{Ya}$ and $\mathrm{Yc}$. The chi-square test indicated that the $\mathrm{Y}$ chromosome variants are not randomly distributed $(\mathrm{p}$-value $=0.00)$.

A significant difference in the geographic distribution of X chromosome morphological variants was observed: $\mathrm{Xa}$ was the most frequent form in all populations (47.5\%; $\mathrm{n}=143)$, followed by $\mathrm{Xb}(22.5 \% ; \mathrm{n}=143)$, and $\mathrm{Xc}$ was only observed in ES-RJ and RS-SC populations (7.7\%; $\mathrm{n}=143)$. The distribution of the $X$ chromosome variants did not follow a clear clinal pattern (Figure $5 \mathrm{c}$ ). Nevertheless, the chi-square test revealed significant differences in the frequencies of $\mathrm{X}$ chromosome variants among populations $(\mathrm{p}$-value $=0.005)$.

\section{Discussion}

\section{Chromosomal polymorphisms}

Oligoryzomys nigripes is one of the most polymorphic species of Neotropical rodents. A total of 432 karyotypes would be expected considering all combinations of the polymorphisms involving pairs $2(2 \mathrm{~A}$ or $2 \mathrm{M}), 3(3 \mathrm{~A}, 3 \mathrm{H}$ or $3 \mathrm{M}), 4(4 \mathrm{~A}, 4 \mathrm{H}$ or $4 \mathrm{M}), 8(8 \mathrm{H}$ or $8 \mathrm{M}), \mathrm{X}(\mathrm{Xa}, \mathrm{Xb}$ or $\mathrm{Xc})$ and $\mathrm{Y}(\mathrm{Ya}, \mathrm{Yb}, \mathrm{Yc}$ or $\mathrm{Yd})$. So far, only 46 of these cytotypes have been observed, representing only $10.6 \%$ of the theoretically predicted forms.

The heteromorphism of pair 3 is widespread in the species. The synaptonemal complexes analyses indicated that these heteromorphisms do not pose a problem for the synapsis and segregation of the homologues during meiosis in heterozygotes. Several genetic mechanisms seem responsible for overcoming meiotic disturbance in heteromorphic rodents, such as the occurrence of heterosynapsis

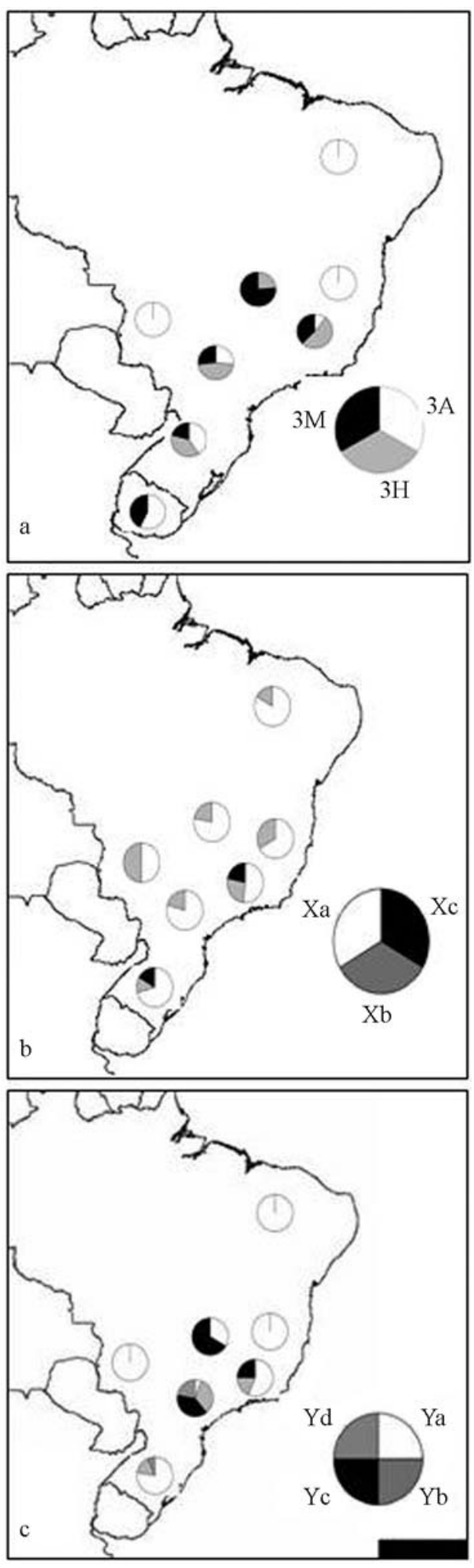

Figure 5 - Geographical distributions of the frequencies of the polymorphic forms of (a) pair 3, (b) X chromosomes and (c) Y chromosomes.

(Fagundes et al., 1998) and a low frequency of chiasmata between inverted segments (Wang et al., 2003a). Moreover, wild rodent populations showed high numbers of heterozygous individuals without any evidence of fertility re- 
duction (Greenbaum and Reed, 1984; Hale, 1986). Mechanisms as the ones mentioned above are likely to be operating in Oligoryzomys nigripes populations, thus reducing the deleterious effects associated with heterozygous pericentric inversions.

Almeida and Yonenaga-Yassuda (1991) described the frequencies of heterozygotes and homozygotes for pair 3 in populations from São Paulo, which were shown to be in Hardy-Weinberg equilibrium.

Sex chromosomes polymorphisms are common in Oryzomyini and are usually due to constitutive heterochromatin additions/deletions (Almeida and Yonenaga-Yassuda, 1991). Three variants of Y chromosomes were found in $O$. nigripes populations from the states of São Paulo and Rio de Janeiro. This variation was attributed to either constitutive heterochromatin duplications or pericentric inversions (Almeida and Yonenaga-Yassuda, 1991).

Five out of 11 other Oligoryzomys species showed sex chromosomes polymorphisms due to constitutive heterochromatin variation: O. stramineus (V.M. Furtado unpublished data), O. magellanicus (Gallardo and Palma, 1990), O. longicaudatus (Gallardo and González, 1977), O. flavescens (Espinosa and Reig, 1991) and O. fulvescens (Haiduk et al., 1979).

Multani et al. (2001) classified the constitutive heterochromatin of mammals into three types: telomeric, nontelomeric and a combination of both. Different types of repetitive sequences have been observed in rodents. Heterogeneity of sex chromosomes heterochromatin was either attributed to differences in DNA-protein associations (Murer-Orlando and Richer, 1983) or to repetitive elements and sequence composition (Modi, 1993). Our data revealed that the heterochromatin of the sex chromosomes of Oligoryzomys nigripes is not related to repetitive telomeric sequences, and thus we believe that they are associated to DNA-protein association.

\section{Frequencies}

Only $10.6 \%$ of the expected cytotypes to occur in $O$. nigripes have already been found (46 out of 432). The chi-square test showed significant differences in the distribution frequency of the variants of pair 3 , the $\mathrm{X}$ and $\mathrm{Y}$ chromosomes, indicating that some variants are exclusive to specific geographical areas. Thus, the total number of possible theoretical combinations $(n=432)$ is unlikely to occur.

In the rodent Akodon cursor, Fagundes et al. (1998) proposed that 81 karyotypic combinations were expected to exist, although only $34.6 \%$ of them had been observed.

The occurrence of a rearrangement in a particular geographical area could be related to a positive adaptive value. Baker et al. (1983) proposed that natural selection may favor the fixation of a chromosomal rearrangement that promotes a genetic benefit to the carrier.
In an attempt to correlate karyotypic with environmental features, Confalonieri and Colombo (1989) studied 103 individuals from six Trimerotropis pallidipennis (Orthoptera) populations from Argentina, distributed along an altitudinal gradient. These authors observed a high correlation between frequencies of chromosomal inversions and altitude. Later, Confalonieri (1994) investigated 281 individuals from 17 Argentinian populations and detected a positive correlation between the frequency of heterozygotes and the altitude and longitude in which they lived. According to Confalonieri (1994), T. pallidipennis fits into a balanced model in which the selection coefficient varies according to the altitudinal, latitudinal and longitudinal gradients. The major selective forces could be climatic and/or ecological variables associated to these gradients, such as temperature, humidity, oxygen rate, atmosphere pressure, precipitation and length of daylight.

Most studies that described the occurrence of chromosomal rearrangements in wild rodent populations made no correlation to environmental components. The major difficulty is determining patterns of rearrangements occurrence because of either small sampling or insufficient number of geographical areas studied (Bianchi et al., 1969; Liascovich et al., 1990; Almeida and Yonenaga-Yassuda, 1991; Sbalqueiro et al., 1991; Castro et al., 1991; Andrades-Miranda et al., 2001; Wang et al., 2003b).

Although our data showed a high correlation between specific chromosome variants and the geographic area where they were found, we were unable to associate specific cytotypes to any ecological or environmental features in Oligoryzomys nigripes.

\section{A model of karyotypic evolution for Oligoryzomys nigripes}

We propose a hypothetical evolutionary pattern and radiation scenario for Oligoryzomys based on the hypothesis that the original differentiation area of the oryzomyines was the Andean region of Ecuador, Colombia and Venezuela (Savage, 1974; Reig, 1978, 1984, 1986). The ancestral oryzomyine (proto-oryzomyini) had reached the northwestern coast of South America and quickly dispersed into the highlands that emerged during the Inferior Miocene. The subsequent Andean elevation of the Cordillera had increased the heterogeneity of the Andean environments, leading to the differentiation of the ancestral lineage of Oryzomyini which adapted to the different habitats of the mountainous jungle. Other oryzomyines had simultaneously diversified into habitats of lower elevations, invading the lowlands of the northwestern Andes and later reaching southern lower areas. It is likely that Oligoryzomys originated with adaptations to live in low prairies and with herbivory trends (Reig, 1984).

Indeed, we clearly observed that the geographical distribution of $O$. nigripes coincides with tropical and subtropical humid forests (Figure 1), suggesting that this sort of 
environment could play the role of a dispersal corridor for Oligoryzomys, as previously suggested by Reig (1984).

Considering that the lowlands of the western Brazilian and the Paraguayan prairies could be the region where Oligoryzomys originated, the populations of these areas could carry the most primitive characters of the genus. Based on this idea, we suggest that the karyotype with $2 \mathrm{n}=62 / \mathrm{FN}=80$ is the $O$. nigripes primitive karyotype. This karyotype is composed of a submetacentric pair 2, an acrocentric pair 3 and metacentric pairs 4 and 8 . These are the chromosome variants present in all specimens from Mato Grosso do Sul and in most individuals from Paraguay. Subsequently, specimens showing the acrocentric form of pair 2, the heteromorphic and metacentric forms of pair 3 , the heteromorphic and acrocentric forms of pair 4 , and the heteromorphic form of pair 8, would have originated during the radiation of the ancestral group towards the lowlands of southern Brazil, Uruguay and Argentina, reaching the Atlantic coast of southern and northeastern Brazil.

Populations in lowland islands of Argentina, Uruguay and Santa Catarina/Rio Grande do Sul showed acrocentric or heteromorphic pair 3 and metacentric pairs 4 and 8 . Some lineages with the most derived karyotypical constitution (metacentric pair 3, heteromorphic and acrocentric pair 4 and heteromorphic pair 8) would have spread towards Minas Gerais, São Paulo, Rio de Janeiro/Espírito Santo and Bahia (to the eastern and northern portions of the geographical distribution). Lineages from Ceará (northeast) have an acrocentric pair 2, a derived condition.

The clinal distribution of the chromosomal polymorphisms corroborates this hypothesis. The acrocentric pair 3 and metacentric pairs 4 and $8(\mathrm{FN}=80)$ prevailed in the western populations. Southern populations presented individuals with pericentric inversion of pair 3, but the acrocentric form predominated. The frequency of the acrocentric pair 3 form decreased in eastern and northern populations (São Paulo, Rio de Janeiro/Espírito Santo, Minas Gerais and Bahia), while the frequency of the presumed derived metacentric form increased.

The clinal variation observed regarding the $\mathrm{Y}$ chromosome reinforces the differences among the populations from west/south and east/north: the frequency of Ya decreases and the frequency of Yc increases towards the east and north of the geographic distribution.

This work presents new data that allowed us to hypothesize an evolutionary model for Oligoryzomys nigripes based on chromosome variants. We also correlated chromosome variants to specific geographical areas which can be further investigated in order to evaluate the adaptive value of chromosome rearrangements as proposed by Barker (1983).

\section{Acknowledgments}

We thank Dr. Yuri L. R. Leite for suggestions on a previous version of the manuscript. We are also grateful to
Dr. Alexandre P. Aguiar (UFES) for the critical review of the manuscript. Several specimens were collected by Dr. Alexandre U. Christoff, Alexandre Percequillo, Ana Paula Carmignotto, Cláudia Regina Silva, Diego Queirolo, Juliana Lovo and Marcelo Passamani. Rogério Ribeiro (IPEMA, Brazil) helped in the fieldwork and Miriam Silva and Cynthia Esteves in the lab work. This work was supported by Conselho Nacional de Desenvolvimento Científico e Tecnológico (CNPq), Fundação de Amparo à Pesquisa do Estado de São Paulo (BIOTA/FAPESP) and World Wildlife Fund (WWF). Roberta Paresque was a recipient of a Master's scholarship from Coordenação de Aperfeiçoamento de Pessoal de Nível Superior (CAPES).

\section{References}

Almeida EJC and Yonenaga-Yassuda Y (1991) Pericentric inversions and sex chromosome heteromorphisms in Oryzomys nigripes (Rodentia, Cricetidae). Caryologia 44:63-73.

Andrades-Miranda J, Oliveira LFB and Lima-Rosa AV (2001) Chromosome studies of seven species of Oligoryzomys (Rodentia, Sigmodontinae) from Brazil. J Mamm 82:10801091.

Baker RJ, Koop BF and Haiduk MW (1983) Resolving systematic relationships with $\mathrm{G}$ bands: A study of five genera of South American cricetine Rodents. Syst Zool 32:403-416.

Bianchi NO, Contreras J and Dulout FN (1969) Intraspecies autosomal polymorphism and chromosome replication in Akodon molinae (Rodentia, Cricetidae). Can J Genet Cytol 11:233-242.

Bonvicino CR and Weksler M (1998) A new species of Oligoryzomys (Rodentia, Sigmodontinae) from northeastern and central Brazil. Z Säug 63:90-103.

Bonvicino CR, D' Andrea PS and Borodin PM (2001) Pericentric inversion in natural populations of Oligoryzomys nigripes (Rodentia, Sigmodontinae).Genome 44:791-796.

Brum-Zorrilla N, Fronza TG and Wainberg R (1988) Oryzomys flavescens and $O$. delticola chromosomes (Rodentia, Cricetidae) from Uruguay and Argentina. Caryologia 41:275-288.

Cabrera A (1961) Catalogo de los mamiferos de America del Sur. Rev Mus Arg Cien Nat 4:1-732.

Castro EC, Mattevi MS and Maluf SW (1991) Distinct centric fusions in different populations of Deltamys kempi (Rodentia, Cricetidae) from South America. Cytobios 68:153-159.

Confalonieri VA (1994) Inversion polymorphisms and natural selection in Trimerotropis pallidipennis (Orthoptera): Correlations with geographical variables. Hereditas 121:79-86.

Confalonieri VA and Colombo PC (1989) Inversion polymorphisms in Trimerotropis pallidipennis (Orthoptera): Clinal variation along an altitudinal gradient. Heredity 62:107-112.

Espinosa MB and Reig OA (1991) Cytogenetics and karyosystematics of South American oryzomyine rodents (Cricetidae, Sigmodontinae). Z Saug 56:306-317.

Fagundes V, Christoff AU and Yonenaga-Yassuda Y (1998) Extraordinary chromosomal polymorphism with 28 different karyotypes in the neotropical species Akodon cursor (Muridae, Sigmodontinae), one of the smallest diploid numbers in rodents $(2 n=16,15$ and 14). Hereditas 129:263-274. 
Gallardo MH and González LA (1977) Sex chromosome polymorphisms in Oryzomys longicaudatus philippii (Rodentia, Cricetidae). Experientia 33:312-314.

Gallardo MH and Palma E (1990) Systematics of Oryzomys longicaudatus (Rodentia, Muridae) in Chile. J Mamm 71:333-342.

Greenbaum IF and Reed MJ (1984) Evidence for heterosynaptic pairing of the inverted segment in pericentric inversion heterozygotes of the deer mouse (Peromyscus maniculatus). Cytogenet Cell Genet 38:106-111.

Greenbaum IF, Hale DW and Fuxa KP (1986) The mechanism of autosomal synapsis and the substaging of zygonema and pachynema from deer mouse spermatocytes. Chromosoma 93:203-212.

Haiduk MW, Bickham J and Schmidly DJ (1979) Karyotypes of six species of Oryzomys from Mexico and Central America. J Mammal 60:610-615.

Hale DW (1986) Heterosynapsis and suppression of chiasmata within heterozygous pericentric inversions of the sitka deer mouse. Chromosoma 56:425-432.

Liascovich RC, Bárquez RM and Reig OA (1990) Multiple autosomal polymorphism in populations of Akodon simulator simulator Thomas, 1916 from Tucumán, Argentina (Rodentia, Cricetidae). Genetica 82:165-175.

Lima JFS, Bonvincino CR and Kasahara S (2003) A new karyotype of Oligoryzomys (Sigmodontinae, Rodentia) from Central Brazil. Hereditas 139:1-6.

Loidl J, Nairz K and Klein F (1991) Meiotic chromosome synapsis in a haploid yeast. Chromosoma 100:221-228.

Modi WS (1993) Heterogeneity in the concerted evolution process of a tandem satellite array in meadow mice (Microtus). J mol Evol 37:48-56.

Multani AS, Ozen M and Furlong CL (2001) Heterochromatin and interstitial telomeric DNA homology. Chromosoma 110:214-220

Murer-Orlando M and Richer CL (1983) Heterochromatin heterogeneity in Chinese hamster sex bivalents. Cytogenet Cell Genet 35:195-199.

Musser GG and Carleton MD (2005) Family Cricetidae. In: Wilson DE and Reeder DM (eds) Mammal Species of the World: A Taxonomic and Geographic Reference. 2nd edition. Smithsonian Institution Press, Washington and London, pp 501-755.

Myers P and Carleton MD (1981) The species of Oryzomys (Oligoryzomys) in Paraguay and the identity of Azara's "rat sixième ou rat à tarse noir". Misc Publ Mus Zool Univ Michigan 161:1-41.

Reig OA (1978) Roedores cricetideos del Plioceno Superior de la Província de Buenos Aires (Argentina). Mus Munic Cien Nat "Lorenzo Scaglia" 1:1-161.

Reig OA (1984) Distribuição geográfica e história evolutiva dos roedores muroideos Sulamericanos (Cricetidae, Sigmodontinae). Rev Bras Genet 8:333-365.

Reig OA (1986) Diversity patterns and diferentiation of high Andean rodents. In: Vuilleumier F and Monasterio M (eds) High Altitude Tropical Biogeography. Oxford University Press, New York, pp 404-440.

Savage JM (1974) The isthmian link and evolution of Neotropical mammals. Nat Hist Mus Los Angeles County 260:1-51.

Sbalqueiro IJ, Mattevi MS, Oliveira LF and Solano MJV (1991) B chromosome system in populations of Oryzomys flavescens
(Rodentia, Cricetidae) from southern Brazil. Acta Theriol 36:193-199.

Seabright M (1971) A rapid technique for human chromosomes. Lancet 2:971-972.

Sumner AT (1972) A simple technique for demonstrating centromeric heterochomatin. Exptl Cell Res 75:304-306

Thomas O (1917) On small mammals from the Delta of the Parana. Ann Mag Nat Hist 8:96-97.

Wagner A (1845) Diagnosen einiger neuen Arten von Nagern und Handflüglern. Archiv Nat 11:145-149.

Wang JX, Zhao XF and Deng Y (2003a) Chromosomal polymorphism of mandarin vole, Microtus mandarinus (Rodentia). Hereditas 138:47-53.

Wang JX, Zhao XF and Koh HS (2003b) Chromosomal polymorphisms due to heterochromatin growth and pericentric inversions in white-bellied rat, Niviventer confucianus, from China. Hereditas 138:59-64.

Weksler M and Bonvicino CR (2005) Taxonomy of pigmy rice rats genus Oligoryzomys bangs, 1900 (Rodentia, Sigmodontinae) of the Brazilian Cerrado, with the description of two new species. Arq Mus Nac Rio de Janeiro 63:113-130.

\section{Appendix}

For some of the records, Global Position System (GPS) information provided by the authors were used, and in some cases the geographic position of the municipality administrative center collected from the Brazilian Institute of Geography and Statistics (IBGE) was used.

Present Study and Silva MJJ [Estudos cromossômicos e de complexos sinaptonêmicos em roedores brasileiros da Tribo Oryzomyini (Cricetidae, Rodentia). MSc Dissertation, Universidade de São Paulo, São Paulo, Brazil, 1994] - Brazil. Ceará: Pacoti (04¹3'

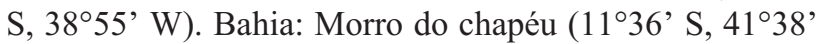
W). Espírito Santo: Santa Tereza (195 $\left.55^{\prime} \mathrm{S}, 40^{\circ} 36^{\prime} \mathrm{W}\right)$, Duas Bocas $\left(20^{\circ} 16^{\prime} \mathrm{S}, 40^{\circ} 28^{\prime} \mathrm{W}\right)$, Santa Maria de Jetibá

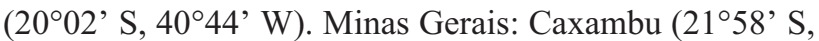
$44^{\circ} 55^{\prime}$ W), Serra da Canastra $\left(20^{\circ} 18^{\prime}\right.$ S, $46^{\circ} 35^{\prime}$ W). São

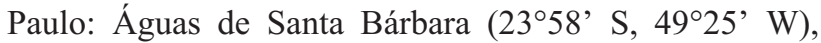

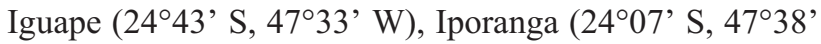

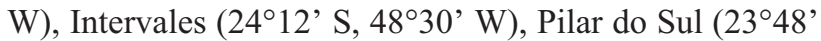
S, $47^{\circ} 42^{\prime}$ W), Araçariguama ( $23^{\circ} 26^{\prime}$ S, $47^{\circ} 03^{\prime}$ W), Santo

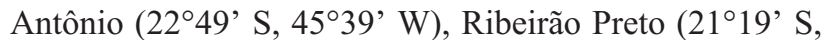

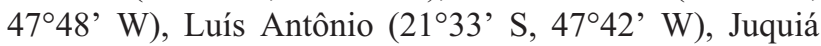
$\left(24^{\circ} 19^{\prime}\right.$ S, $47^{\circ} 38^{\prime}$ W). Mato Grosso do Sul: Serra da Bodoquena $\left(20^{\circ} 42^{\prime}\right.$ S, $\left.56^{\circ} 51^{\prime} \mathrm{W}\right)$. Rio Grande do Sul: Maquine $\left(29^{\circ} 40^{\prime}\right.$ S, $50^{\circ} 10^{\prime}$ W), São Francisco de Paula (31 ${ }^{\circ} 46^{\prime}$ S, $52^{\circ} 19^{\prime} \mathrm{W}$ ).

Almeida and Yonenaga-Yassuda (1991) - Brazil.

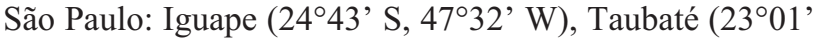
S, 45 $32^{\prime} \mathrm{W}$ ), Pedro de Toledo ( $\left.24^{\circ} 16^{\prime} \mathrm{S}, 47^{\circ} 13^{\prime} \mathrm{W}\right)$,

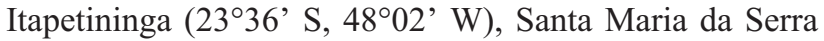

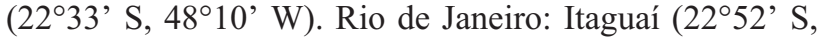

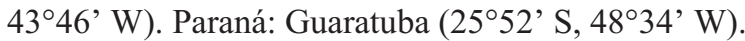

Andrades-Miranda et al. (2001) - Brazil. Goiás:

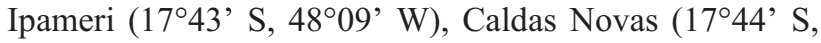
$48^{\circ} 37^{\prime}$ W), Corumbaíba $\left(18^{\circ} 08^{\prime} \mathrm{S}, 48^{\circ} 33^{\prime} \mathrm{W}\right)$. Paraná: 
Parque Nacional do Iguaçu (2530' S, 5430' W). Rio Grande do Sul: Derrubadas $\left(27^{\circ} 15^{\prime}\right.$ S, $\left.53^{\circ} 52^{\prime} \mathrm{W}\right)$, Aratiba

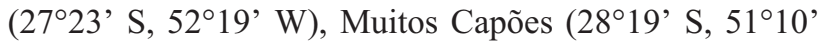
$60 \mathrm{~W})$, Ivaí $\left(29^{\circ} 01^{\prime} \mathrm{S}, 53^{\circ} 47^{\prime} \mathrm{W}\right)$, Tupanciretã (2904' S, $\left.53^{\circ} 51^{\prime} \mathrm{W}\right)$, Caxias do Sul $\left(29^{\circ} 10^{\prime} \mathrm{S}, 51^{\circ} 10^{\prime} \mathrm{W}\right)$, Tainhas

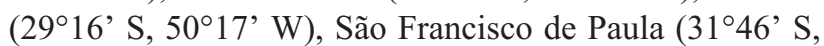
$\left.52^{\circ} 19^{\prime} \mathrm{W}\right)$, Charqueadas (29॰58' S, $\left.51^{\circ} 37^{\prime} \mathrm{W}\right)$, Sapiranga

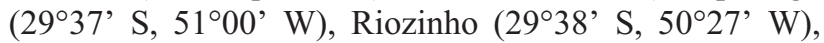
Faxinal $\left(30^{\circ} 18^{\prime} \mathrm{S}, 5^{\circ} 40^{\prime} \mathrm{W}\right)$, Torres $\left(29^{\circ} 21^{\prime} \mathrm{S}, 4^{\circ} 43^{\prime}\right.$ W), Rio Jacuí ( $\left.30^{\circ} 05^{\prime} \mathrm{S}, 5^{\circ} 36^{\prime} \mathrm{W}\right)$, Belém Novo (30¹1'

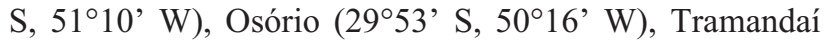

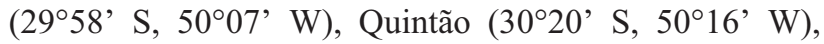

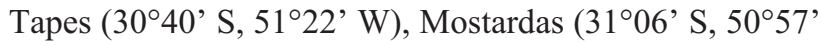
W), Rio Grande ( $32^{\circ} 01^{\prime}$ S, $52^{\circ} 04^{\prime}$ W). Santa Catarina: Florianópolis $\left(27^{\circ} 34^{\prime} \mathrm{S}, 48^{\circ} 34^{\prime} \mathrm{W}\right)$, Concórdia $\left(27^{\circ} 13^{\prime} \mathrm{S}\right.$, $\left.52^{\circ} 01^{\prime} \mathrm{W}\right)$.

Bonvicino et al. (2001) - Brazil. Minas Gerais: Peirópolis $\left(19^{\circ} 43^{\prime} \mathrm{S}, 47^{\circ} 45^{\prime} \mathrm{W}\right)$, Juramento (16 49' $\mathrm{S}$,

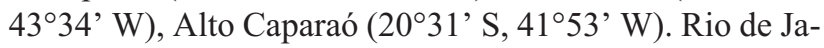
neiro: Teresópolis $\left(22^{\circ} 25^{\prime} \mathrm{S}, 42^{\circ} 58^{\prime} \mathrm{W}\right)$, Nova Friburgo ( $\left.22^{\circ} 16^{\prime} \mathrm{S}, 42^{\circ} 31^{\prime} \mathrm{W}\right)$, Sumidouro (22 $\left.2^{\circ} 03^{\prime} \mathrm{S}, 42^{\circ} 40^{\prime} \mathrm{W}\right)$. São Paulo: Rio Claro $\left(22^{\circ} 23^{\prime} \mathrm{S}, 4^{\circ} 32^{\prime} \mathrm{W}\right)$, Intervales

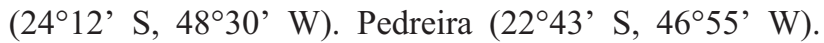
Santa Catarina: Florianópolis $\left(27^{\circ} 34^{\prime} \mathrm{S}, 48^{\circ} 34^{\prime} \mathrm{W}\right)$, Ita $\left(27^{\circ} 16^{\prime} \mathrm{S}, 52^{\circ} 19^{\prime} \mathrm{W}\right)$.

Brum-Zorrilla et al. (1987) - Uruguay. Maldonado (34 $\left.58^{\prime} \mathrm{S}, 54^{\circ} 57^{\prime} \mathrm{W}\right)$, Paysandu (32 $\left.04^{\prime} \mathrm{S}, 5^{\circ} 55^{\prime} \mathrm{W}\right)$,

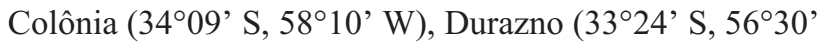
$\mathrm{W})$.

Myers and Carleton (1982) - Argentina. Las Palmas $\left(27^{\circ} 04^{\prime} \mathrm{S}, 58^{\circ} 42^{\prime} \mathrm{W}\right)$, Caraguatay (263' $\left.\mathrm{S}, 5^{\circ} 46^{\prime} \mathrm{W}\right)$. Paraguay. Ibycuí $\left(26^{\circ} 01^{\prime} \mathrm{S}, 5^{\circ} 02^{\prime} \mathrm{OW}\right)$, Carayaó $\left(25^{\circ} 10^{\prime}\right.$ S, 56 $23^{\circ}$ W), Cerro Corá (22 $37^{\prime}$ S, $55^{\circ} 58^{\prime}$ W), Pedro Juan Caballero (22 $\left.34^{\prime} \mathrm{S}, 56^{\circ} 46^{\prime} \mathrm{W}\right)$, Sommerfeld Colony

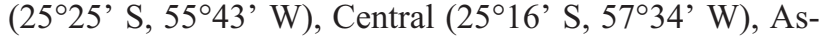
sunción $\left(25^{\circ} 16^{\prime} \mathrm{S}, 57^{\circ} 40^{\prime} \mathrm{W}\right)$, Itapua (2719' $\mathrm{S}, 5^{\circ} 53^{\prime}$ W), San Rafael ( $27^{\circ} 07^{\prime}$ S, $\left.56^{\circ} 22^{\prime} \mathrm{W}\right)$, Rio Pirapó (26 $51^{\circ}$ '

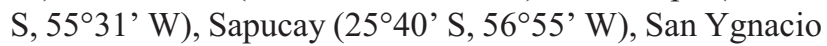

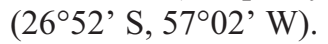

Svartman M (Levantamento cariotípico de roedores da região do Distrito Federal. MSc Dissertation, Universidade de São Paulo, São Paulo, Brazil, 1989) Brazil: Brasília $\left(15^{\circ} 46^{\prime} \mathrm{S}, 4^{\circ} 55^{\prime} \mathrm{W}\right)$.

Zanchin NIT (Estudos cromossômicos em orizominos e equimídeos da Mata Atlântica. PhD thesis, Universidade Federal do Rio Grande do Sul, Porto Alegre, Brazil, 1988) - Brazil. Bahia: Rio de Uma (15¹8' S,

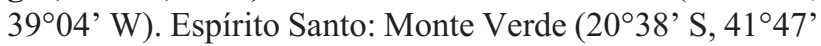

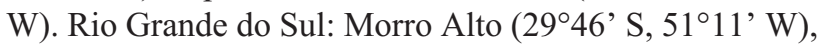

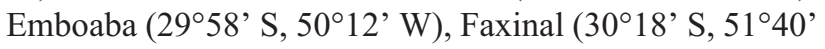
W), Alto Ferrabraz $\left(29^{\circ} 35^{\prime} \mathrm{S}, 50^{\circ} 56^{\prime} \mathrm{W}\right)$, Picada Verão

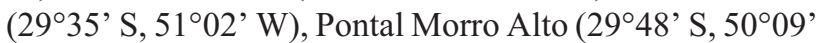
W). São Paulo: Casa Grande (22 $25^{\circ}$ S, $\left.49^{\circ} 55^{\prime} \mathrm{W}\right)$.

Sbalqueiro ij (análises cromossômicas e filogenéticas em algumas espécies de roedores da região Sul do Brasil. PhD Thesis, Porto Alegre, Brazil 1989) - Brazil. Paraná: Piraquara $\left(25^{\circ} 26^{\prime} \mathrm{S}, 49^{\circ} 03^{\prime} \mathrm{W}\right)$. Rio Grande do Sul: Taim $\left(32^{\circ} 02^{\prime} \mathrm{S}, 52^{\circ} 05^{\prime} \mathrm{W}\right)$. Esmeralda $\left(28^{\circ} 03^{\prime} \mathrm{S}\right.$, $\left.51^{\circ} 11^{\prime} \mathrm{W}\right)$, Porto Alegre $\left(30^{\circ} 01^{\prime} \mathrm{S}, 51^{\circ} 13^{\prime} \mathrm{W}\right)$, Tupanciretã (2904' S, 5350' W).

Geise L [Os roedores Sigmodontinae (Rodentia, Muridae) do Estado do Rio de Janeiro: sistemática, citogenética, distribuição e variação geográfica. $\mathrm{PhD}$ Thesis, Universidade Federal do Rio de Janeiro, Rio de Janeiro, Brazil, 1995] - Brazil. Minas Gerais: Viçosa $\left(20^{\circ} 45^{\prime} \mathrm{S}, 42^{\circ} 53^{\prime} \mathrm{W}\right)$. Rio de Janeiro: Nova Friburgo $\left(22^{\circ} 26^{\prime} \mathrm{S}, 42^{\circ} 32^{\prime} \mathrm{W}\right)$.

Espinosa and Reig (1991) - Argentina. Buenos Aires: Isla Ella (3440’ S, 58³0’ W).

Associate Editor: Fausto Foresti 